\title{
A JOURNEY BEYOND THE BOUNDARIES OF ANAESTHESIA
}

\author{
Lakshman Karalliedde, MBBS, FRCA \\ Consultant Medical Toxicologist \& Visiting Senior Lecturer, \\ King's College, London, UK
}

The deck of playing cards took precedence over medical texts and lectures as winning the contract bridge championship for two consecutive years with Sarath Kapuwatte as my partner and mastering the art of cut table techniques were considered more wholesome, which perhaps would satisfy you sir, Dr B S Perera-a contract bridge enthusiast, of my credentials to honour you this evening. My dear friend Sheriffa, if I may call that esteemed surgeon reminded me, that people are invited to deliver orations for several reasons, they deserve it, it is the cheapest option or there is no one else available. Whatever it may be, it is my privilege and pleasure to pay a tribute to you.

Besides your mastery in the specialty of anaesthesia which spanned both hemispheres, I was made aware of the hours you spent with several of your friends and colleagues playing contract bridge-including the Jeyaratnams'-two of their sons are present today to honour you.

The commitment and dedication of pioneers like your self could best be described by a quote from 1931 when William Hutchinson in the Chairman's Address at the California Medical Association said "If the detail men of those days were anything like those of today, I can imagine one entertaining Dr Jones's office-of course a surgeon's officetelling him of the simplicity of this applicationhow anyone could use it with safety-just drop it on a towel or handkerchief and the patient will go to sleep and the surgeon could do his work at leisure. Under such conditions it is not surprising that the administration of an anaesthetic was relegated to the nurse, relative or someone off the street. Soon charlatans were procuring supplies of ether and traveling over the countryside picking up jobs as they could-naturally followed by high mortality.
Had it not been that anaesthesia was absolutely essential to surgical advance, I doubt if anaesthesia could have withstood the disrepute. Because of the high risk of complications and the number of deaths following such administration of anesthetics, physicians became aware of the dangers associated with the anaesthesia and began studying and training themselves. The work of these men is responsible for the specialty of anaesthesia today.

I had the rare privilege of interviewing Dr Lucas in the early 1980's and he presented me with his impeccably documented anaesthetic records. It was my folly and a regrettable irresponsibility that I did not take adequate care to ensure their safety. For these notes exemplified the skills and techniques which pioneers such as you used to ensure patient safety.

Your varied skills and talents as a Consultant Anaesthetist for nearly 50 years in pioneering cardiac and hypotensive anaesthesia in Sri Lanka were duly mentioned by the president.

\section{Boundaries}

Theme of boundaries encompasses several aspects of life, educational activities not being an exception. In medicine, it is often forgotten that the current safe boundaries were once unknown frontiers.

Boundaries indicate defined spaces whether sacred or secular which are invariably considered as zones of protection- formed or imposed by an individual or group of individuals with common interests or agendas. Boundaries formed the arena within which the conflicts that operated in a confined space became visible and the competition 
for hierarchical precedence was both overt and covert.

Historically, and in my mind to date, boundaries have limited enterprise and impeded multidisciplinary approaches forming barriers at the interfaces of closely associated specialties with great damaging effect preventing the establishment of refreshing vibrant connections across subject areas for example the basic sciences, pharmacology, general medicine and anaesthesia.

By many, the overt temporal and spatial limitations of boundaries were overlooked to ensure security, though the term stability was often used and the concept of monopoly was craftily dispensed with-i.e. to ensure that activities within the boundary cannot be intruded by those outside the boundary.

It is appropriate to relate the anecdote associated with the brother of Dr. B.S. Perera- Late Dr G N Perera who was the first genito-urinary surgeon in Sri Lanka. There was a controversy about Dr G N performing hydrocoelctomies, initiated by the general surgeons as criminal trespass and a violation of their boundary rights established with Prior registration at the Land Registry- Apparently at an inquiry held at the highest levels, Dr G N had defended his actions effectively by stating that "when I was young, my grandmother told me that anything between my thighs are genital".

For any interaction across boundaries it is necessary to understand space. Your space.

\section{My perception of boundaries of anaesthesia}

To me, in the practice of anaesthesia there was an intrusive, intimidating and insulting attitude to the intellect, intelligence and image of a fellow professional.

Exemplified in the gratuitous advice to give more "Oxygen and keep the Pressure up "or Instructions like "give a little pento" or "just hold a mask", can you adjust the light as I cannot see properly etc This caused frustration, restlessness and disappointment. In this context, I salute those who persisted and brought honour and the due respect to the specialty in Sri Lanka whilst I ran away and pursued activities on the boundaries of anaesthesia which I believe was as much a search for selfrealization as well as to extend and merge the boundaries of anaesthesia with other medical specialties.

I would illustrate in perhaps the most civilized manner, what I perceived in every sphere of activity as an anaesthetist with these cricketing photographs e.g. whether batting or fielding within the boundary which was the operating theatre

However there were moments of glory when an irritated trainee anaesthetist- Dawood by name, who responded to a condescending surgeon when asked -what are you giving now- by saying medicine, the impact being illustrated. David Chanmugam as Physician, OPD Kandy put an end to the practice of surgeons referring to physicians regarding fitness for anaesthesia in the late 1960's at G.H.Kandy.

Without any reservations, I pay due tributes to the likes of Kenneth Perera who practiced anaesthesia as a specialty with pride and total commitment to excellence on the sound foundations of basic sciences, Thistle Jayawardene who started the first Intensive Care Unit in Sri Lanka, Deepthi Attygalle and Nalini Rodrigo who fought their way through to establish internationally recognized teaching and training programmes to confer a long awaited recognition and respectability to the speciality, along with many others such as Ranjan Fernando, Jayantha Jayasuriya, Ganeshamoorthy, mavericks in the likes of Dawood and the energetic and skilled younger generation who-too many to mention for fear of unpardonable omissions consolidated and ensured the stability, sustainability and development of the speciality and the College to as the president aptly commented - "to What we are".

To those of us in anaesthesia, the perceived and accepted view of health and esteemed medical bodies was to facilitate surgery in the operating theatres. These views were virtually carved in stone as I realized when attempting to establish an academic department of anaesthesia at the Peradeniya Medical faculty where the tortuous road with a multitude of attitudinal hurdles towards departmental status involved acceptance 
initially by the Department of Surgery to which I was attached, the members of the Faculty Board at Peradeniya, the Senate of the Peradeniya University and the University Grant's Commission.

My commitment to establishing an academic department arose from my exposure to the Magill department of anaesthetics at Westminster Hospital following an introduction to Sir Geoffrey Organe in Sri Lanka by Dr PAP Joseph. That was my first exposure to an academic department of anaesthesia. I never realized or imagined the spectrum of activities of such a department and the respect other specialities had for the dynamism and vibrant mileu within the department. The Clinical Head was appointed the Dean of the Faculty of Medicine. The concept and potential of academic anaesthesia gripped me ever since.

To change is difficult, not to change is fatal.

growth leads to change. Stepping from the known to the unknown and the search for areas/regions where exchange is possible

\section{How do I reach or cross the boundaries}

This was the imaginary path that I considered:

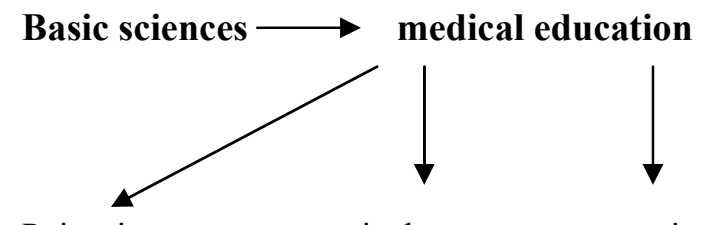

Poisoning

toxicology

envenoming

Kandy Hospital became a vibrant mileu where an atmosphere of creativity and enthusiasm for development prevailed following the establishment of the Medical faculty. Amongst the major developments was the establishment of the Kandy Society of Medicine led by Varagunam, Rudra Rasaratnam and Kolitha Karunartane and of the Medical Education Unit, both of which were encouraged by the first visionary Dean of the Faculty Senaka Bibile. The Faculty staff and Hospital Consultants worked in harmony and there was a productive informality between the teachers and students.

During internship, Gandhi Nelson encouraged me to publish on Amniotic fluid embolism in the Journal of the Department of Obstetrics and
Gynaecology. The initial excursions research or study was with the Medical Education Unit with the assistance of Palitha Abeykoon and Susil Gunasekera along with Nimal and Arjuna when we studied the attitudes and career preferences of medical students in relation to anaesthesia-which were published in Medical Education and Medical teacher in early 1980 's, If one compares the career preferences in 1980's to the quantum of anesthetists today in Sri Lanka, the surge taking to the specialty is a tribute to the persistence of those whose conduct changed public and professional perceptions for graduates with the availability of sound post graduate teaching, training programmes and placements overseas-perhaps feminine aggression and uncompromising attitudes which were discomforting to the male professionals in other discipline. It was Rudyard Kipling who said "The female of the species is deadlier than the male'.

A documentary for public health education to promote immunization in tetanus, use of gastrostomies for feeding and use of physiotherapy following cessation of spasms followed assisted by surgeons-Philip Veerasingham, Kulatillaka and Edwards in particular. During this period at Kandy Hospital, the management of tetanus gradually shifted to anaesthetists from general surgeons. In Sri Lanka, Deepthi Attygalle and Nalini Rodrigo along with their teams pioneered the use of magnesium in the management of tetanus. Recently I was informed by some members of the clinical staff at Peradeniya Hospital that it was difficult to find a patient with tetanus to teach medical students.

This I consider as a major advance in the spectrum of clinical care provided by anaesthetists outside the operating theatres.

However, these activities prompted comments from learned colleagues at the Peradeniya Medical Faculty this as an odd anaesthetist who has not published anything on anaesthesia-essentially re: putting people to sleep and waking them after surgery.

Though hurtful on occasions, it was a great relief when journals such as Anaesthesia, British Journal of Anaesthesia and the European Journal of 
Anaesthesia accepted and on occasions invited me to write several review articles, editorials and papers on the very subjects that were considered unacceptable by the Faculty at Peradeniya.

Following my involvement with Nimal Senanayake in the study of OP poisoning, I happened to treat a patient following krait envenoming. The cause of death in both instances was respiratory failure. Whilst following krait envenoming, we were aware that the lesion was essentially at the neuromuscular junction (NMJ) due to binding of the venom which contained bungarotoxin to the binding site of $\mathrm{ACh}$, we were totally ignorant as to how OP agents would cause effects at the NMJ. Of course there was awareness of the accumulation of the neurotransmitter ACh due to phosphorylated inactivation of AChE.

What emerged was that if ventilatory care was provided in both case scenarios, recovery would be complete - no sequelae, except following poisoning with neuropathic OP agents where the possibility of OP induced delayed polyneuropathyOPIDN was a distinct possibility.

Following the exposure associated with mental and physical trauma during the isolated arm studies done with Stanley Feldman, when he isolated both my arms and injected muscle relaxants and recorded the responses following different rates of nerve stimulation, I was at least able to discuss on level terms re the NMJ with Nimal.

Feldman carried out several studies on me and also on himself for hours. On one occasion he injected me with the muscle relaxant using distilled water instead of saline which caused intense pain and I was close to screaming when he said- I knew you would not stand this for too long. I was in intense pain for nearly five minutes, with stimuli applied to my nerves, when he returned with a $50 \mathrm{ml}$ syringe of saline and injected $25 \mathrm{ml}$ to each arm, which brought immediate relief. Without any visible expression of sympathy he said, we have to now abandon this study but we shall repeat the studies next week. The only expression of sympathy or concern during these studies was the instruction that I should not drive for at least 1 hour after the studies-I did not want to inform him that in any case I could not drive because I had almost the whole range of visual disturbances that accompanied parenteral administration of muscle relaxants following the release of the tourniquets.

We pursued our studies to determine degree of neuromuscular deficit that occurred during the IMS. It became obvious that we needed a nerve muscle stimulator which was gifted to us by Bertie Dundas from Aberdeen-their old one which had been replaced recently, which was brought as precious hand baggage from London.

Nimal and I were able to describe the responses to tetanic stimulation during the phase of muscle paralysis following OP poisoning and thus our findings became publishable.

Muscle weakness following OP poisoning was described earlier by Wadia et al from India which they termed type II paralysis but they too possibly lacked facilities for nerve stimulation. Our studies aroused international interest because of the awareness caused of the risk of death due to respiratory failure after apparent recovery from the acute cholinergic phase-albeit in a rather primitive manner.

Whilst we were attributing symptoms of OP poisoning in essentially an illogical manner, on arriving in the UK at the tender age of 50 years, I was exposed to the likes of Bill Bowman, Tim Marrs, Bob Maynard, Anthony Adams and to Feldman again. We pursued studies on the acetylcholine receptors-nicotinic in particular, though we all accepted that the manifestations of the cholinergic phase were predominantly muscarinic, we were uncertain as to what occurred at the post synaptic nicotinic receptor.

It was a wholesome, inspiring period where I was emotionally affected by their humility, humour and honesty. My only wish was that Nimal could have been there. Their attire at times made me look like Gregory Peck in the Grey Flannelled Suit.

They stimulated me to work further and shared all their knowledge without any hint of arrogance or a patronizing approach. They said- get on and show how animal toxins affect neuromuscular function- 
for the British Journal of Anaesthesia-To this day I do not know whether it was a request or an order. However, I was pleased with the product.

I found it invigorating when requested to study enevenoming in detail-crossing boundaries from anaesthesia to haematology, neurology, nephrology etc. Prof David Warrell guided me along with physiologists from Strathclyde and our own Anslem Silva which resulted in the diagrams for Davidson's Principles and Practice of Medicine- the $20^{\text {th }}$ edition which has outsold all previous editions of this gospel in medicine.

However, both Nimal and I were convinced that we were seeing the tip of the iceberg. With the funding available through SACTRC, Dr Pradeepa Jayawardena was able to conduct single fibre electromyography which revealed the spectral nature of the intermediate syndrome and also the results of the forme fruste form in a journal with a double figure impact factor. However, there is and was more to do. Does the nicotinic receptor undergo atrophy, death, or is it a rotation of the subunits which results in varying degrees of muscle weakness and the variations in the period of recovery. Towards obtaining further information, we are seeking funding for stimulated single fibre electromyography to study to study 'jitter' - a phenomenon quite distinct from what one gets before a sporting event or a political event or an examination. It would reveal to us the nature of change that takes place at the nicotinic receptor which would perhaps enable us to use drugs such as the muscle relaxants we use during an aesthesia to occupy the alpha units and prevent the changes or damage caused by the loss of acetylcholinesterase activity. This would be similar to the use of the carbamates such as pyridostigmine in the military for soldiers likely to be exposed to nerve gases to mop up the organophosphates and enable the release of acetylcholinesterase more quickly.

Meanwhile along with Tim Marrs and Philippa Edwards we began collating data to determine variability of responses to OP agents. Essentially this is what we found which was published in Chemical safety.
Our literature searches revealed that nACHRs could be Structurally distinct- Functionally -there could be distinct transition states for an individual nACHR

Therefore nAChR ligands may therefore be considered to differentially stabilize the conformational states to which they preferentially bind.

A more persistent modulation of $\mathrm{nAChR}$ function can occur by phosphorylation of the receptor protein

Phosphorylation can enhance the rate of nAChR desensitization and increase the frequency of spontaneous channel openings.

Receptor nomenclature in the $\mathrm{nAChR}$ area has been derived from classical pharmacology approaches, including receptor sensitivity to snake toxins. Following from Dale's conceptualization of ACh receptor subtypes over 80 years ago, Barlow, Paton and Zaimis showed that the antagonist decamethonium (C10) was more effective than hexamethonium (C6) in blocking muscle nAChRs, whereas C6 was effective in autonomic ganglia [83]. This led to the description of 'C10 ' (muscle) and 'C6' (neuronal) receptors. Muscle nAChRs are pseudoirreversibly blocked by bungarotoxin ( $\square$-BgT). Ganglionic nAChRs are competitively blocked by trimethaphan, and resistant to snake $\square$-toxins, yet sensitive to neuronal bungarotoxin (n-BgT: also known as $\square$-BgT, $\square$-BgT 3.1, or toxin F).

From the first few months of my starting as a consultant anaesthetist with the Ministry of Defense, I was offered a study day every week to work with Late Professor John Henry, an authority on drugs of abuse, particularly ecstasy and poisoning, at the Guy's Poisons Unit. I need to mention that this was not following a request made by me, the Head simply stated you have a day to pursue your interests and perhaps you know John Henry.

Thus began another journey to the unknown territory - drugs of abuse, biochemical toxicology, adverse reactions and overdose. The Unit had developed an interest in the toxicology of 
Traditional herbal medicines with Debbie Shaw being employed solely to work on this subject

We realized the association between Nicotinic receptors in tobacco addiction. And that these receptors also enhance the long-term effects of cocaine and amphetamines. Thus developed a merger surrounding the acetyl choline receptors

Humans have used drugs for thousands of years, to alleviate pain, seek pleasure, cure diseases and relieve mental suffering.

The result of these activities was that there were no boundaries for those trained in anaesthetics. This was confirmed when I resigned my post as Senior Lecturer in Anaesthetics at Guys and $\mathrm{St}$ Thomas' and was absorbed by the Guy's Poison's Unit and started on a steep learning curve in Toxicology.

Acceptance of material on the boundaries of anaesthesia by the leading British Journals in Anaesthesia and on anaesthesia related subjects in journals such as Chemical Safety, Journal of Public Health, Forensic Science International, Journal of Infection, in the least satisfied, my conviction of the need to cross boundaries and blend with other disciplines.

When I was invited to write a preface for a book on Neurology by neurologists in South America, albeit in Spanish, I felt further vindicated re my curiosity over the world beyond the traditional horizons. When invited to lecture at the Royal Society of Medicine-Anaesthesia Division, on animal toxins I threw caution aside and followed an old saying- let your heart guide you and then open it and hear it calling you.

I am not ashamed to admit that I became a student again at the age of 55years + , certainly more committed and enthusiastic than I was at Medical College. The hours the wizards spent educating me on subjects ranging from toxicity of heavy metals, drugs of abuse, body stuffers and body packers, interpretation of analytical results from samples of hair blood, urine, nails, neuromuscular junction, chemical warfare agents to drug overdose and traditional medicines with a blend of affection and insult made me wonder why on earth should they be doing this to me. Later Virginia Murray, the pioneer in the management of chemical incidents in the UK and with colleagues at King's such as Norman Parkinson taught me the basics of air pollution, water contamination, hazards of fires, industrial pollution and associated aspects of environmental and occupational toxicology.

It was a freedom of learning and exchange of knowledge without as we say 'strings attached' which I, unfortunately never experienced or encountered during my career as an anaesthetist in Sri Lanka. I felt like a bird flying freely in space without boundaries.

The time spent in full time toxicology which is more than a decade quenched my thirst for knowledge. I realized that I was being virtually pushed or even propelled to levels of knowledge competence furthest from my wildest dreams.

Reality was that I was being taught, guided, encouraged and provided with opportunities, whose existence was new to me. They were true colleagues, intellectuals for whom institutions were more important than individuals. They were secure in sharing knowledge and in constant pursuit of stretching towards excellence or perfection. These colleagues who spent hours teaching me later became our family friends and looked forward to end a working day at my home with a rice and curry meal and of course, a pint or two or a claret of wine. The result that I was requested to provide opinions/defend or prosecute international organizations such as UniLever, del Monte and Emirates and apera for the Crown. Those involved in international drug trade have no hesitation in employing barristers who would strip an expert witness similar to piranha attacking a victim.

Here my training and practice of anaesthesia was possibly of great benefit- the need to think on one's feet and make quick decisions and provide effective responses. There conflicting interpretation of blood gas analytical results following exposure to chlorine in a swimming pool and where the charge was murder by the administration of heroin intravenously-the sequential development of respiratory failure following overdose with opioids became a 
contentious issue between the two expert witnesses.

These are illustrations of the benefits of exposure to varied disciplines during one's medical career. Anaesthesia is built on sound foundations of physiology and pharmacology, necessitates quick reaction times and develops prolonged periods of attention to what many may consider minutiae. These aspects cannot in my experience be dismissed as inconsequential or those that could or should be done by those with' no exceptional skills or knowledge.

One satisfying enterprise which ultimately realized its potential was the formation of SACTRC.

A pitfall for any one attempting pay tributes or thanks for any venture results in omissions and often offence.

Professionally Professors HS Kirthisinghe, Senaka Bibile and Barr Kumarakulasinghe sent me on the path towards academia. Nimal pushed me along this path which was directed, narrowed and destinations indicated by Professors Tony Adams, Bill Bowman and Stanley Feldman which were reached in collaboration with the likes of John Henry, Tim Marrs, Virginia Murray, Debbie Shaw. Palitha Abeykoon facilitated international collabolarations and links with countries in South East Asia. Tissa Kappagoda's scientific rigour, discipline and attention to detail guided me on many an occasion. Clinically I cannot forget my mentors, the amiable Chokka Fernando and Debonair Upali Weerackody. I owe a debt to Arjuna Aluwihare as Head of Surgery who supported the establishment of the Academic department of Anaesthesia and in this context, Deepthi Attygalle from the Board of study had a decisive role.

My professional journey was essentially one seeking self-realization. My journey in life was one of adventures and misadventures, risks, thrills and spills, fantasies, frolic, frivolity intermingled with fragility and fallibility.

To me, my personal relationships and encounters are without any doubt more treasured.
With Sheriffa, Poops, Susiri, we ventured to Europe and with my Pakistani urologist we attempted a journey by car from London to Colombo which was abandoned in Iran due to the Indo Pakistan conflict in 1971.

It has been exciting, tortuous and often traumatic and it is impossible for me to express my gratitude to so many who have spontaneously supported me. My friends have been rough diamonds whose loyalty has never known boundaries.

Close family members provided my brother and self with accommodation, pocket money etc in Colombo whilst we were studying at law and medical Colleges when my parents were financially fragile. During serious ill health, beginning with a malignancy in my mother in late 1960 's, family and friends rallied spontaneously and supported in every conceivable manner.

The mavericks for whom I have always had overt admiration selflessly crossed boundaries with sincerity, loyalty seeking no rewards which I value immensely. Memories are many, Harry Rasiah moving in with his huge Alsation dog as my room mate, batting with Suruttuwa Amarasekera at the other end whose softest whisper could be heard a mile away, Chang who assaulted the first Silva he encountered at Trinity when his brother complained that Silva hit him and Gordon Burrows reprimanding Odayar 'Odayar, I cannot call you a thief but you are soon becoming one'. Odayar never crossed that boundary.

There were noble deeds of my friends such as refusal of ambassadorial posts, caring on a daily basis for my mother and sick brother and for Kanthi's ageing father during the twenty years we were abroad and to date neither Kanthi and I know what the expenses were. These are several of the debts that we cannot repay adequately.

In essence, there are many debts that I cannot ever repay.

Kanthi has stood by my side patiently for nearly forty years across hemispheres in my search of mirages and delusions. She provided me the rock solid base to take all the risks-as she made sure that the family was watered, fed and sheltered . 
Perhaps, most importantly she made certain that my feet were firmly on the ground. Her sensitivity, belief in social justice and devotion to the care of disabled and less fortunate beings and the innate simplicity has been a source of comfort, solace and worthy of admiration.

These are some of the satisfactory end points of some journeys. This is a unique photograph of a unique human being. The only photograph in a formal dress for he never would pose for a photograph. His patience, dedication, devotion to students, school and country, innovative thoughts and deeds such as the Trinity farm are legendary. Above all, he had compassion and humility, arrogance, ridicule of others, materialism were unknown to him, I can never remember him using the cane, but his soft whispered words often in confidence has inspired me for over 55 years. He knew of no boundaries. He did cross a physical boundary when he delivered a can of milk over the Suisse wall for our children for nearly ten years. He was essentially a dreamer and I am pleased that I have been able to fulfill some of the dreams he did say he had for me.

Whilst preparing this oration, I learnt much about patterns of human behavior. One aspect was with how we talk about each other and comment on the life of someone else. We get locked in these running narratives about who we think a person is and how he or she conducts his or her life. Once the story we tell about others is formed and takes over our thoughts, feelings, perceptions and assumptions we have crossed a boundary that does not belong to us. This process of taking over another person's story entails not allowing him or her to tell their own story and defend themselves. The act of crossing a boundary from this point of view is negating the voice of the person we are commenting on and in affect acting out their needs, wants, desires and motives for him or her.

Thank you, the Council of the College of Anaesthesiologists for inviting me to deliver this oration named after one of the greats of anaesthesia an honour in the twilight of my career.

My wish is that during my journeys through sansara, I would have the pleasure of associating again with the mavericks, whose loyalty and risk taking behaviour and fiercely independent thought and noble deeds have been inspiring.

Life is perpetually creative because it contains in itself that surplus which overflows the boundaries of the immediate time and space, restlessly pursuing its adventure of expression in the varied forms of self-realization. R Tagore (1861-1941) 1913. 